laws of the Union were adopted, and the adhesion of Great Britain, the United States, Canada and Norway was recognized. Commissions of the Union were established as follows : Acta Crystallographica, International Tables, Structure Reports, Crystallographic Apparatus, Nomenclature, Crystallographic Data. Crystallographers throughout the world interested in the work of any of these Commissions are invited to make contact with them through the General Secretary. The second General Assembly and Congress will be held in Europe during the summer of 1951 .

\section{Mechanization of African Agriculture}

Problems likely to be encountered in the mechanization of African agriculture are to be studied by a mission which is visiting Uganda, Tanganyika, Nyasaland and Nigeria. The leader is Dr. J. R. Raeburn, of the Agricultural Economics Research Institute, Oxford, and he is accompanied by Mr. J. W. Y. Higgs, lecturer in agricultural economics, University of Reading, and Mr. R. K. Kerkham, Uganda Agricultural Service, who is at present stationed at the Uganda Agricultural Research Station. The terms of reference are : "To make a systematic survey of the sociological, economic, agricultural and technical problems which must be studied if mechanization of agriculture in the Colonies is to develop along sound lines, including inter alia the forms or organization required to achieve the best results (for example, whether mechanization should be on a co-operative, group or peasant basis), the most profitable lines of future research into problems arising out of mechanization, the economics of it and the types of tractors and implements which would be likely to be most suitable to the differing African communities, and such questions as the tech. nical training of African craftsmen, the division and displacement of labour which will result from mechanization and its impact on current farming and social systems."

\section{Colonial Service Appointments}

THe following appointments in the Colonial Service have been announced: A. Bolton, plant breeder, Kenya; E. A. Rosenquist, botanist, Malaya; J. A. F. Gerrard, geophysicist, Uganda; A. D. Campbell, veterinary officer, Nigeria; D. W. D'Silva, assistant conservator of forests, British Honduras; H. T. Hayes, fisheries officer, Gold Coast; G. H. Lunam, fisheries officer, Nigeria; D. M. Rhodes, fisheries officer, Uganda; O. E. Symes, fisheries development officer, Nigeria ; T. R. Hayes (principal agricultural officer, Uganda), assistant director of agriculture, Uganda ; R. B. Jagoe (botanist, Federa. tion of Malaya), senior botanist, Federation of Malaya ; H. T. Pagden (entomologist, Federation of Malaya), senior entomologist, Federation of Malaya; D. H. Welsh (agricultural officer, Nigeria), principal of schools, Agricultural Department, Nigeria; D. B. Fanshawe (assistant conservator of forests, British Guiana), senior assistant conservator of forests, British Guiana.

\section{Effect of Lightning Discharge}

Prof. E. W. Marchant, 20, Harthill Road, Liverpool, 18, writes: "During a severe thunderstorm in Liverpool on July 31, the centre of the roadway was struck by lightning. The lightning discharge produced a crack about six feet long in the asphalte road surface near the centre of the road and close to a manhole cover, which, I understand, was open at the time of the storm. Six or seven pieces of melted tar were scattered over the road close to the crack. Heavy rain was falling at the time and the interesting thing about the discharge was that it struck the flat surface of the road, although, only thirty feet away on each side, were trees about twenty feet high."

\section{Announcements}

Dr. Andrif Danjon, director of the Paris Observatory, has been elected a member of the Section of Astronomy of the Paris Academy of Sciences, in succession to the late Dr. Henri Deslandres.

Dr. W. A. Macfarlane, director of fuel efficiency in the Ministry of Fuel and Power, has been lent by the Ministry to the Department of Scientific and Industrial Research for about two years for appointment as director of the United Kingdom Scientific Mission in the British Commonwealth Scientific Offices in Washington. He will also be attaché for scientific matters in the British Embassy. In accordance with arrangements made at the time of his appointment, the present director of the Mission, Dr. F. N. Woodward, is returning to the United Kingdom towards the end of the year.

THE Public Health and Municipal Engineering Congress and Exhibition will be held at Olympia, London, during November 15-20. Further information can be obtained from the Joint Hon. Secretary, 84 Eccleston Square, London, S.W.1.

THE twenty-third annual conference of the Association of Special Libraries and Information Bureaux (ASLIB) will be held at Ashorne Hill, near Leamington Spa, Warwickshire, during September 17-20. Further information can be obtained from the Secretary, ASLIB, 52 Bloomsbury Street, London, W.C.1.

The Council of the Royal Society of Arts is offering, under the Thomas Gray Memorial Trust, the objects of which are "the Advancement of the Science of Navigation and the Scientific and Educational interests of the British Mercantile Marine", a prize of $£ 50$ for an essay on "The Applications of Radar to Navigation". Further information can be obtained from the Secretary, Royal Society of Arts, John Adam Street, Adelphi, London, W.C.2.

The South African Journal of Science of March 1948 reports the Oudtshoorn meeting in July 1947 of the South African Association for the Advancement of Science. It includes the presidential address by Prof. H. H. Paine, "The World View of the Physicist", and the addresses of the sectional presidents. Of these, Prof. C. C. Gillie reviewed "A Century of Astrophysics", Dr. C. N. C. Hamilton dealt with "Coal", Prof. A. Quintanilha with "The Problem of Cotton Production in Portuguese Africa", Dr. C. S. Grobbelaar with "Anthropometry and its Role in South Africa", the Abbé H. Breuil with "Ancient Raised Beaches and Prehistoric Civilizations in South Africa", and J. D. Rheinallt Jones with "The Development of Central and Southern Africa", including a few suggestions for research and action on some of the problems common to these territories. A number of the papers read at the meeting are also printed. 